\title{
DEDE KORKUT KITABI'NDA YAPI, IDEOLOJI VE YARATIM -Dresden ve Vatikan Nüshalarının Mukayeseli Bir İncelemesi-
}

\author{
PEHLIVAN, Gürol (2015), Dede Korkut Kitabı'nda Yapı, İdeoloji ve Yaratım \\ -Dresden ve Vatikan Nüshalarmın Mukayeseli Bir İncelemesi-, İstanbul: \\ Ötüken Yayınları, 606 s., \\ ISBN: 978-605-155-318-4.
}

Ergün VEREN*

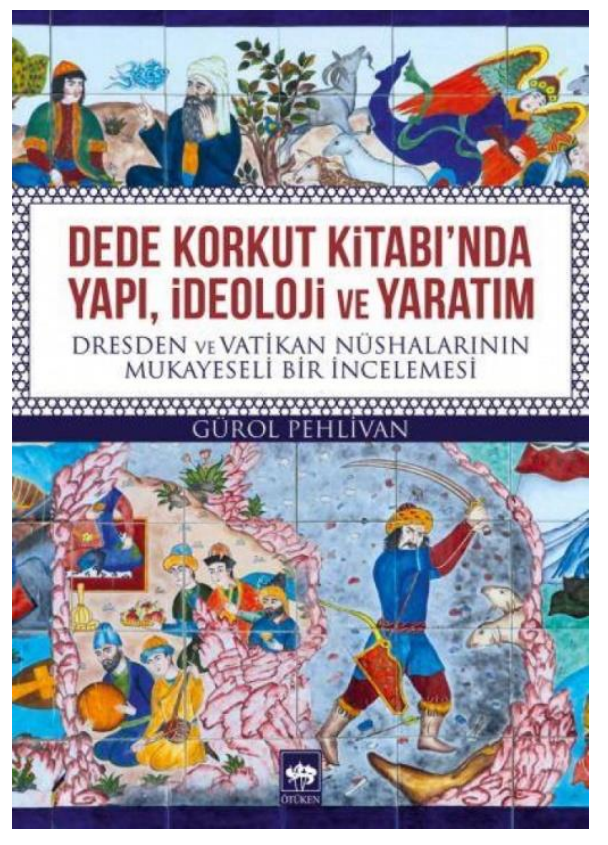

Dede Korkut Kitabı üzerine bu güne kadar tez, makale ve kitap olarak 1638 'in üzerinde, çok sayıda çalışma yayımlanmıştır.

“Dede Korkut Kitabı'nda Yapı, İdeoloji ve Yaratım" kitabı da bunlardan biridir ve "... eserde geçen, dolayısıyla yazar/şair/anlatıcıya ait olduğu düşünülen düşünce/duygu, ona mi müstensihe mi ait? ... eserden ayrı olarak müstensihlerin de ideolojileri var mı?" soruları üzerine inşa edilmiştir. Yazarın halkbilimi alanındaki doktora tezi olan ve öncelikle akademik çevreye hitap eden kitap; Dede Korkut Kitabı'nın Dresden ve Vatikan nüshalarının "müstensihin gücü ve etkisi" odağına yerleştirilerek farklı kuram ve yöntemlerle okunup irdelenerek; analitik ve akademik bilgi olarak üretilmiş bir çalışmadır.

Kitapta, Dede Korkut Kitabı'nın Dresden ve Vatikan nüshaları "müstensihin gücü ve etkisi" odağında; yapı, ideoloji ve yaratım-aktarım başlıkları altında üç bölümde incelenmektedir. Yazar; önsöz ve girişten sonra yapı bölümünde boylardaki kurgu aşamaları ile arasöz ve epitet kullanımları üzerinde dururken; ideoloji bölümünde kitabın ideolojik omurgası ile siyasi/toplumsal/bireysel/ahlaki/dini/eğitim ve ekonomik mesajlarını analiz etmekte; son bölümde yaratıcı-aktarıcı bağlamında sözlü/yazılı yaratım-aktarım sorunları ile zaman ve ortamı inceleyerek; sonuç bölümünde de tezinin doğruluğunu özetlemeye çalışmaktadır.

\footnotetext{
*Yüksek Lisans Öğrencisi, Hacettepe Üniversitesi Türkiyat Araştırmaları Enstitüsü, ergunveren@hotmail.com
} 
Akademik dille oluşturulan kitapta yazarın, bir yanda anahtar sözcükler ile temel kavram ve terimleri yoğun olarak kullanırken diğer yanda bunları metin içinde/dipnotlarda açıklayıp tablolarla desteklemesi kitabı akıcı ve anlaşılır kılmaktadır. Yine yazarın analitik ve çok yönlü yaklaşımı; akademik beklentileri karşılayıcı niteliği; kullanılan kaynakların nitelik ve nicelik bağlamında çalışmayla uyumluluklarının yanı sıra kitapta geniş bir bibliyografya ile indekse yer verilmesi de kayda değer unsurlardır.

Olgusallıkla teori arasında gidip gelen yazarın irdelemelerini temellendirdiği kuram ve kavramların tüm ögelerini kullanmadığı “-arasöz kullanımında İlhan Başgöz'ün ortaya koyduğu üç tip arasöz varlı̆̆ından şahsi serzeniş ve itiraflar sınıflandırmasını kullanmaması gibi-" (s. 196-198); olası eleştirilere de "tahlil noktasında bir teoriye bağlanmak yerine, eklektik bir yönelim sergiledim" (s. 24) sözleriyle "ön-cevap" geliştirdiği görülmektedir.

Yazarın Dede Korkut Kitabı üzerinde yapılan evvelki çalışmalardan akademik bağlamda etkilenmesine karşın "hepsinin konuya dil ve metin tesisi yönünden değinmelerine" (s. 20) karş1 çıkarak bu durumun "... Halkbilimi ürünleri açısından son derece sıkıntılı..." (s. 22) olduğuna vurgu yapmaktadır.

Her iki nüshanın da üslup ve içerik bağlamında farklı yorumlar yapmaya elverişli olduğunu kaydeden yazar; bugüne kadar yapılan çalışmaların aksine nüshaların ayrı ayrı ele alınması gerektiği üzerinde durarak “... her iki nüshanın dayandı̆̆ı ortak bir yazılı metin vardı. Bu metin, sözlü anlatımın yazıya geçirilmiş haliydi. Bugün elimizde bulunan nüshalar, bu ilk metnin müstensihler tarafından, bazı müdahalelerle, yapılmış istinsahlarıdır." (s. 23) görüşünü ortaya koymaktadır.

Mukayeseli yöntemle iki nüshanın metinlerini cümle/paragraf ölçeğinde karşılaştıran yazar; "... alımlama estetiği kuramına göre metnin anlamının yazar ve okur arasındaki konuşma sonucu ortaya çıktığı, yazarın her şeyi söylemek istemediği, boşlukların okuyucu tarafindan doldurulması gerektiği..." (s. 26) savından hareketle metin kırılması ekseninde yüzey yapı-derin yapı analizi ile sonuca gitmeye çalışmaktadır. Öte yandan bir metne tarihselci ya da anlamacı-eleştirel bakış açısıyla yaklaşıldığını hatırlatan yazarın boylara, anlamacı-eleştirel metotla yaklaştığı görülmektedir.

Metindeki cümlelerin arka planındaki ruhi-ideolojik yapıyı keşfetme yönelik çok yönlü bir çalışma yapma gayretinde olduğu gözlenen yazar; Mihail Bahtin'in "monolojizm" varsayımlarından etkilenmesine karşın boylarla varsayımların örtüşmediğini de kabul etmektedir.

Boyların içerdiği sabit fikirlilik, şematik toplumsal rol dağılımı ve kalıp ifade tekrarları ile metin ideolojisi bağlamında adı konulmamış "toplum mühendisliği" girişiminde bulunulduğunu dolaylı olarak dile getiren yazar; olumsuz karakterlerle de "kara" sayesinde " $a k$ "ın ne olduğunun gösterilmeye çalışıldığını ileri sürmektedir.

Destanın sözlü icra sırasında derlenmiş, sonra da bu dip nüshadan çoğaltılmış olduğunu kaydeden yazar nüshaların ortak bir nüshaya dayandığı görüşü üzerinde yoğunlaşırken, nüshalar arasındaki farklılıkların müstensihlerden kaynaklandığını; "Dresden müstensihinin gördüğü dip nüshayı birebir kopyalarken Vatikan müstensihinin aile değerleri konusunda çok hassas, kurgu konusunda oldukça dikkatli, dip nüshada yer alan ve anlamlandıramadığı kelimeleri değiştirerek istinsah edip metnin daha rahat okunmasını sağladığı" (s. 492-493) iddiasında bulunmakta; daha da ileri giderek Vatikan müstensihinin altı boydan oluşan nüshayı mantığı esas alarak kurguya uymayan metinleri çıkararak (s. 493) oluşturduğunu iddia etmektedir.

Geniş zaman aralığında, yoğun çalışma temposuyla hazırlandığı kabul edilen "Dede Korkut Kitabı'nda Yapı, İdeoloji ve Yaratım" kitabında dikkat çekici kimi paradokslar da yok değildir. Bunlar şu şekilde gösterilebilir: 
Yazarın "ben" ve "biz" ikilemi (s. 17-18-195) ile "düşünüyorum" (s. 490-493), "sanıyorum", "belki" (s. 490), "inanıyorum" (s. 490) vb. biçimde birinci tekil şahıs üslubu kullanması; kararsızlığının, güven bunalımının ve tedirginliğinin dışa vurumu mudur sorularını akla getirmektedir. Master tezinin "tespit"; doktora tezinin "ispat" temelinde inşa edildiği düşünülürse akademik çalışmalarda kararlı, güven verici ve konuya hâkimiyeti dışa vuran akademik bir imla kullanılması akla gelmektedir.

Dresden ve Vatikan nüshalarının ortak bir dip nüshadan çoğaltıldığını kaydeden yazarın, Vatikan nüshasının az miktarda "boy" içermesi ve kimi yerlerinde kısaltmaya gidilmesinin göz önünde bulundurarak Vatikan nüshasının Dresden nüshasından yararlanılarak hazırlanma olasılığını gözden uzak tutmaktadır. Öte yandan Vatikan müstensihinin altı boydan oluşan nüshayı mantığı esas alarak kurguya uymayan metinleri çıkardığı iddiasında bulunurken altı boyda da Salur Kazan'ın dâhil olduğu serüvenlerin işlenmesine karşın "Salur Kazan'ın Tutsak Olup Oğlu Uruz'un Çıkarması" boyunun bu nüshaya alınmayışından ve nedeninden söz etmemektedir.

Boylardaki cümlelerin arka planındaki ruhi-ideolojik yapıyı keşfetmeye yönelik çok yönlü bir çalışmaya yönelen yazar; cümle yapısı, anlatım tekniği vb. ögelerden yararlanarak müstensihlerin edebi kimlikleri ve dönemin konjonktürüyle ilişkilerine yönelik bir çıkarım yapamamaktadır. Öte yandan Mustafa Kaçalin "Dedem Korkut'un Kazan Bey Oğuz-nâmesi" kitabında (s. 12-14) Vatikan nüshasının II. Beyazıt'ın oğlu Şehzade Alemşah'a ithafen (1512) hazırlandığını kaydetmektedir. Bu bilgi temelinde Vatikan müstensihinin "maddi kazanç" beklentisi ile hareket ederek kısa zamanda bir nüsha hazırlama kaygısı olasılığı yazar tarafından dikkate alınmamıştır.

Akademik bir çalışma olan söz konusu kitapta kimi popüler terimlerin kullanılması “... 1990'ların sonlarına kadar üvey evlat muamelesi görmüştür." (s. 21), "... ağzından şu manidar kelimeler dökülür." (s. 370), “... başkalarının uyarılarına kulak verilmelidir." (s. 368) dikkat çekicidir.

Son olarak da şu soru akla gelmektedir: Dede Korkut Kitabı sadece itibari bir edebi metin midir? Dede Korkut Kitabı'ndaki boylarda tüm kuramlar ve yöntemler kullanılarak ideoloji, tarih, coğrafya ile ruhi-ideolojik arka plan ya da derin yapı ögeleri aranmalı mıdır? Bu yaklaşım metni ve Dede Korkut'u dar bir coğrafyaya sıkıştırarak yerelleştirir mi?

Sonuçta “Dede Korkut Kitabı'nda Yapı, İdeoloji ve Yaratım” kitabı; üzerinde geliştirilen tartışma ve eleştirilerle birlikte "Dede Korkut Kitabı"ndaki boyların çeşitli kuram ve yöntemlerden yararlanılarak evvelkilerinden farklı olarak okunup irdelenerek; analitik ve akademik bilgi olarak üretilen bir çalışmadır. 